\title{
ASEPTIC MENINGITIS DUE TO INFECTION WITH ECHO VIRUS (TYPE 9)
}

\author{
BY D. M. McLEAN \\ Harrison Watson Student, Clare College, Cambridge \\ AND D. CAMERON \\ Physician in Charge, Brookfields Hospital, Cambridge \\ From the Department of Pathology, University of Cambridge
}

(With 2 Figures in the Text)

Cases of aseptic meningitis occur singly or in groups in many communities nearly every year mainly during the summer and autumn months. Cases of paralytic and non-paralytic poliomyelitis also occur more frequently during these months. Curnen, Shaw \& Melnick (1949) have isolated both poliomyelitis and Coxsackie viruses from cases of aseptic meningitis and non-paralytic poliomyelitis by inoculation of extracts of faeces into monkeys and newborn mice, respectively. With the widespread use of tissue culture techniques in epidemiological studies on poliomyelitis (Melnick, 1954) many strains of virus which are not poliomyelitis or Coxsackie viruses have been isolated from the faeces of cases of aseptic meningitis and non-paralytic poliomyelitis. The term enteric cytopathogenic human orphan (ECHO) virus (Science, 1955) is applied to those viruses which multiply in cultures of human kidney (Kibrick, Enders \& Robbins, 1955), human lung fibroblasts (Svedmyr, Melen \& Kjellen, 1956), human amnion (Zitcer, Fogh \& Dunnebacke, 1955) or monkey kidney (Melnick, 1954), which are not neutralized by typespecific sera prepared against any of the three Types of poliomyelitis virus, which are not Coxsackie viruses, adenoviruses (Enders, Bell, Dingle, Francis, Hilleman, Huebner \& Payne, 1956) or other well-characterized viruses such as influenza and herpes simplex, and which do not regularly cause disease after inoculation into convenient laboratory animals. At least thirteen antigenic types of ECHO virus have been described (Science, 1955). However, it is not only in patients who are ill with aseptic meningitis that these ECHO viruses may be found, because Honig, Melnick, Isacson, Parr, Myers \& Walton (1956) have isolated strains of poliomyelitis and Coxsackie viruses in addition to ECHO viruses from rectal swabs obtained from healthy people. Although the isolation of virus from the faeces of a patient suffering from aseptic meningitis strongly suggests that the organism has caused the disease, this cannot be proved unless a rising titre of antibody to the patient's own virus is detected from paired serum samples.

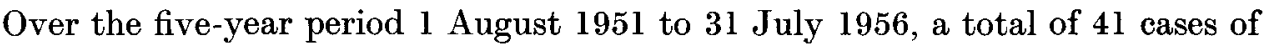
aseptic meningitis, 37 cases of non-paralytic poliomyelitis and 159 cases of paralytic poliomyelitis were admitted to Brookfields Hospital, Cambridge. Not more than three cases per month of aseptic meningitis or non-paralytic poliomyelitis were admitted to hospital except on two occasions-July and August 1953 when a total 
of twelve cases was admitted and between August and November 1955 when twenty-six cases were admitted. It is interesting to note that Huston, Morwood, Christofinis \& Wood (1956) encountered a large number of cases of non-paralytic poliomyelitis in suburban Surrey during October 1955.

Prior to 1951, eight cases of encephalitis occurred in June and July 1949 (Barrett, Gairdner \& McFarlan, 1952) in a village close to the rural area where most of the cases of aseptic meningitis occurred in 1955. The symptomatology of the 1949 cases was quite different from the 1955 cases. In 1949 poliomyelitis virus was isolated from the stools of at least two patients, but in 1955 poliomyelitis virus was not isolated from patients with aseptic meningitis.

The present paper reports clinical and virological investigations on eleven cases of aseptic meningitis which occurred in Cambridgeshire during October and November 1955 in the outbreak referred to above. Virological studies have been facilitated greatly by the use of human amnion cells in tissue culture.

\section{THE OUTBREAK}

Eleven cases of aseptic meningitis occurred in Bourn, Cambridgeshire, and in Cambridge between 17 October and 11 November 1955. Eight patients came from four families who lived under crowded conditions in former R.A.F. huts and a cottage near the village of Bourn. Members of these families visited each other frequently. Two nurses who were on duty in the paediatric ward to which the first two Bourn cases (M.B. and R.C.) were admitted, contracted the disease 8 and 9 days after M.B.'s admission. Some 11 days after nurse E.K. became ill, her husband R.K. also developed similar symptoms. No patient had been in contact with a recognized case of poliomyelitis during the preceding few weeks, although twenty-two cases of paralytic poliomyelitis and four cases of non-paralytic poliomyelitis were admitted to hospital during October and November 1955 from other parts of Cambridgeshire and Essex.

The youngest patient was aged 6 months and the oldest 37 years. The remainder were between 10 and 30 years of age. Seven were male and four female.

In addition to these eleven clinical cases, nine other family contacts out of a total of fourteen tested were shown to have had subclinical infections as shown by the presence of neutralizing antibody in their sera taken on 10 November. Two more developed subclinical infections between 10 November and 1 December 1955 .

The syndrome consisted of sudden onset of severe frontal headache in ten cases out of eleven and this frequently persisted for 3-5 days (Table 1). This was accompanied by backache in eight cases and vomiting in eight cases. Three patients complained of a sore throat, two had severe pain in the legs and two had mild photophobia. There was no biphasic element to the illness in any case. The temperature on admission was $99 \cdot 8^{\circ} \mathbf{F}$., or higher, in all eleven cases. Neck stiffness was a prominent finding in ten cases and it persisted for 4-12 days. No patient developed weakness or paralysis in any muscle. In two cases the lymph glands were somewhat enlarged and the spleen became palpable in one case. 
Lumbar puncture was performed in ten cases within $24 \mathrm{hr}$. after admission and on one case 5 days after admission. In ten cases the cerebrospinal fluid (CSF) contained between 10 and 1180 lymphocytes per $\mathrm{mm} .{ }^{3}$ and eight of these cases also had between 6 and 40 polymorphonuclear leucocytes per $\mathrm{mm}^{3}$. In the one patient (L.R.) whose CSF contained no cells when examined 2 days after onset, a further sample of CSF obtained 7 days after onset contained 261 lymphocytes and 21 polymorphonuclears per $\mathrm{mm}^{3}$ In eight cases the protein concentration was elevated to between 40 and $170 \mathrm{mg} . / 100 \mathrm{ml}$. In ten cases the sugar concentration was between 50 and $75 \mathrm{mg} . / 100 \mathrm{ml}$, but in one case it was as low as $31 \mathrm{mg} . / 100 \mathrm{ml}$.

Table 1. Clinical findings in eleven cases of aseptic meningitis

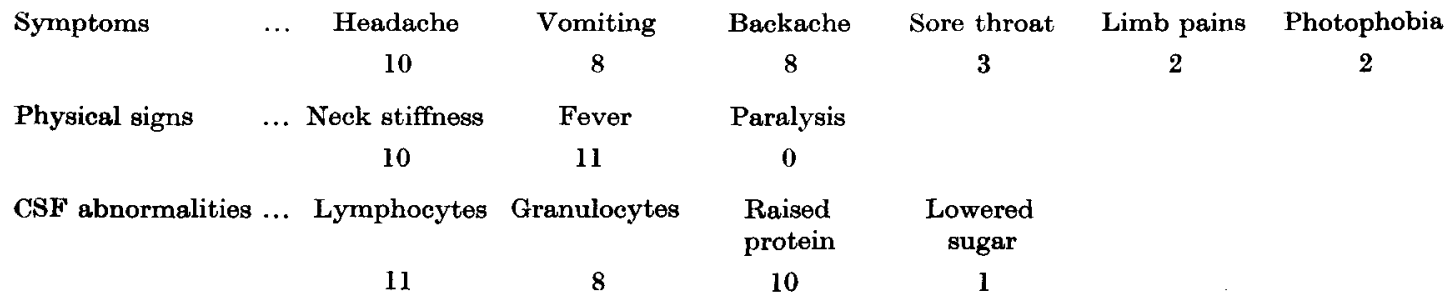

The peripheral blood was examined in eight cases. The total leucocyte count was between 7000 and 11,000 cells per $\mathrm{mm}^{3}$ in three cases and in these the proportion of lymphocytes was between 6 and $20 \%$. In the other five cases the total leucocyte count was between 3400 and $5800 / \mathrm{mm}^{3}$ and the proportion of lymphocytes was between 9 and $47 \%$.

In the case of L.R. whose CSF contained no cells 2 days after the onset of illness, the peripheral blood had 7200 leucocytes per $\mathrm{mm}^{3}$ with $6 \%$ lymphocytes. On the seventh day when the CSF contained 282 cells, the peripheral blood contained 5400 leucocytes per $\mathrm{mm} .^{3}$ of which $45 \%$ were lymphocytes.

Treatment was bed rest for 10-14 days together with aspirin for relief of headache. Thereafter walking was begun gradually. All patients were well and free from symptoms within 3 weeks of onset.

There were three waves of the epidemic (Fig. 1). The first wave consisted of two children, M.B. who was followed by R.C. 5 days later. The second wave consisted of four cases which occurred between 9 and 14 days after onset of M.B.'s illness. The incubation period was between 4 and 9 days. Two of these cases I.M. and M.M. lived at Bourn and two were nurses E.K. and C.W. both of whom nursed M.B. and R.C. in hospital. The third wave was comprised of five cases which occurred 1725 days after onset of M.B.'s illness. Four lived at Bourn (L.R., G.R., H.D.M. and L.M.) and one (R.K.) lived in Cambridge. The incubation period was therefore between 8 and 11 days.

\section{METHODS AND MATERIALS}

Preparation of cultures of human amnion cells. The method used was essentially that described by Zitcer et al. (1955). Foetal membranes from which the placenta had been removed were placed aseptically in sterile screw-capped jars and these 
were held at $4^{\circ} \mathrm{C}$. in a refrigerator until used. Where possible, membranes were used less than $10 \mathrm{hr}$. after delivery but, occasionally, satisfactory results were obtained with membranes stored for $18 \mathrm{hr}$.

The amnion was stripped from the chorion, cut into pieces 1 in. square, washed to remove excess mucus and blood with cold phosphate buffered saline (PBS) (Dulbecco \& Vogt, 1954) and treated with successive $40 \mathrm{ml}$. aliquots of $0.25 \%$ Difco trypsin in PBS, previously warmed to $37^{\circ} \mathrm{C}$. The system was maintained at
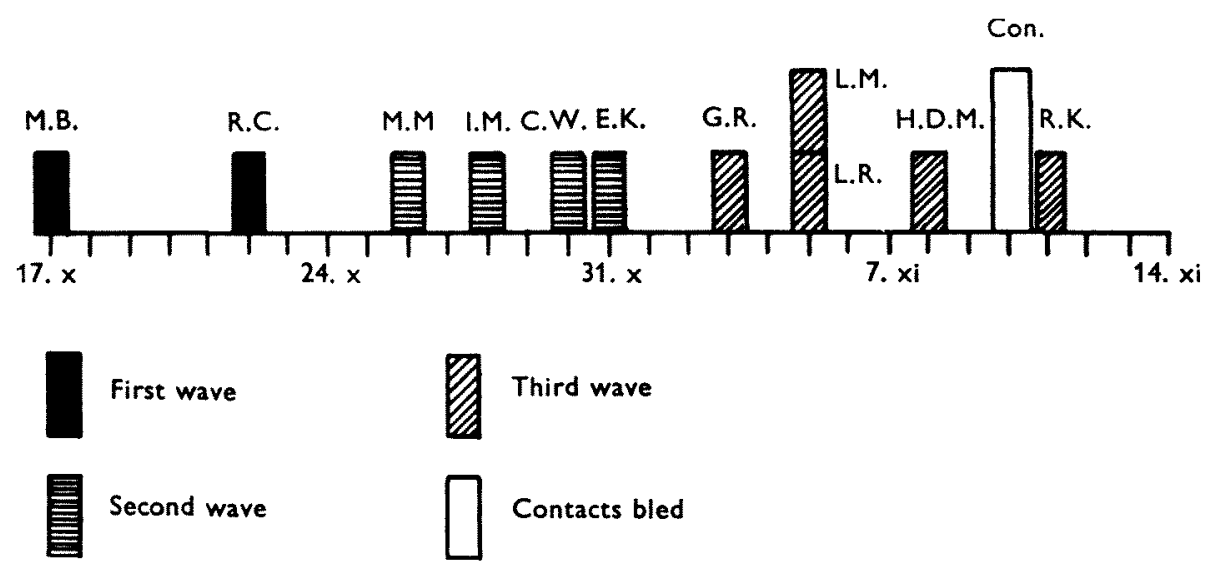

Fig. 1. Three waves of the Bourn epidemic.

$37^{\circ} \mathrm{C}$. on a warm plate and agitated with a magnetic stirrer. Every $15 \mathrm{~min}$. the supernatant which contained epithelial cells which had separated from the amnion sheets was poured off into a $200 \mathrm{ml}$. centrifuge bottle which was cooled in an ice bath. Fresh trypsin was then added to the amnion. A total of six such trypsinizations was carried out. The suspensions containing epithelial cells were pooled and the whole was centrifuged at 1000 r.p.m. for $10 \mathrm{~min}$. in a horizontal centrifuge. After washing once in PBS the cells were suspended in $10 \mathrm{ml}$. of a medium containing $20 \%$ human serum and $0.5 \%$ lactalbumin hydrolysate in Gey's (1949) balanced salt solution. After a cell count was made the cell suspension was diluted with the same medium so as to contain not less than 500,000 cells per $\mathrm{ml} .1 \mathrm{ml}$. quantities were pipetted into $5 \times \frac{5}{8}$ in. Pyrex tubes which were stoppered with silicone bungs and incubated stationary at $37^{\circ} \mathrm{C}$. inclined at $5^{\circ}$ from the horizontal.

After 3 days incubation at $37^{\circ} \mathrm{C}$. sheets of epithelial cells had begun to spread over the glass surface. The medium was poured off and replaced by $1 \mathrm{ml}$. of a medium containing $10 \%$ normal rabbit serum (previously heated at $60^{\circ} \mathrm{C}$. for $20 \mathrm{~min}$. and $0.5 \%$ lactalbumin hydrolysate in Gey's solution. After a further 3 days incubation, a confluent sheet of flattened cuboidal cells with clear cytoplasm and large rounded or oval nucleus had formed. The cells were now ready for inoculation with virus.

Immediately prior to inoculation, the cultures were washed twice with Gey's solution. Finally, $1 \mathrm{ml}$. quantities of a maintenance medium consisting of $5 \%$ normal rabbit serum and $0.25 \%$ lactalbumin hydrolysate in Gey's solution were 
added to each tube and the virus inoculation was made into this fluid. Uninoculated cultures remained intact in this maintenance medium for at least 10 days.

All media which were used during the growth and maintenance of the tissue cultures contained penicillin 100 units $/ \mathrm{ml}$, streptomycin $100 \mu \mathrm{g} . / \mathrm{ml}$. and Nystatin (Squibb) 40 units $/ \mathrm{ml}$.

Isolation of virus from faeces or rectal swabs. Faeces were collected less than 1 week after onset of illness and were stored in screw-capped jars at $-20^{\circ} \mathrm{C}$. After thawing, $a \frac{1}{2}$ in. pellet of faeces was ground in a sterile mortar and extracted with $10 \mathrm{ml}$. of cold PBS. The suspension was centrifuged at 8000 r.p.m. for $25 \mathrm{~min}$. in an angle centrifuge, the head of which was previously cooled at $-20^{\circ} \mathrm{C}$. The clear supernatant which was now free of bacteria was stored in screw-capped bottles at $-20^{\circ} \mathrm{C}$.

Rectal swabs were extracted with $2 \mathrm{ml}$. of maintenance medium. The extract was centrifuged and stored in the same manner as the faecal extracts.

Faecal extract in $0.1 \mathrm{ml}$. aliquots was inoculated into each of two culture tubes containing $1 \mathrm{ml}$. of maintenance medium. The cultures were observed daily for 5 days. When more than half the cells were rounded up, with shrunken nuclei and opaque, granular cytoplasm, so that the sheet of cells was disrupted, it was considered likely that virus was present in the faecal extract. The supernatant fluids were harvested, pooled and stored at $-20^{\circ} \mathrm{C}$. to await further identification. Cytopathogenic effects were usually well developed on the third or fourth day.

Typing of virus strains. Virus strains were typed according to the method of Syverton (1956) using eight tubes of human amnion cultures. Type specific antisera prepared in monkeys against poliomyelitis Types 1,2 and 3, which were used, were obtained through the courtesy of Dr D. G. ff. Edward.

Titration of virus. Serial tenfold dilutions of first or second passage virus in tissue culture fluid were made in maintenance medium. $0.1 \mathrm{ml}$. aliquots of these dilutions were inoculated into each of two tubes. The tubes were observed daily for 4 days. One tissue culture infective dose (TCD) was the reciprocal of the highest dilution of stock virus which caused advanced cytopathogenic effects in one or both culture tubes after inoculation of $0.1 \mathrm{ml}$.

Neutralization test. Serum samples which were obtained from patients and contacts were stored at $-20^{\circ} \mathrm{C}$. until tested. Serial fivefold dilutions of serum were made in Mixture 199 (Morgan, Morton \& Parker, 1950) or Gey's solution commencing at 1/10. An equal quantity of virus, diluted in maintenance medium to contain 1000 TCD was added. The serum-virus mixtures were held at room temperature for between 15 and $45 \mathrm{~min}$. after which $0.75 \mathrm{ml}$. aliquots were added to each of two culture tubes from which all fluid had been removed. The tubes were observed daily for 4 days. Virus controls and uninoculated cultures were always included in every test. The titre of the serum was expressed as the reciprocal of the highest dilution which caused inhibition of cytopathogenic effect in one or both culture tubes. 


\section{RESULTS \\ Virus isolations}

Virus was isolated from the faeces of two patients, L.M. and L.R., by inoculation of human amnion cell cultures with extracts of faeces obtained on the second and third day of illness, respectively. These two viruses behaved similarly in tissue culture and serologically they were indistinguishable (Table 2). From the same stool specimen taken from L.R. on the third day of illness, virus was isolated in cultures of monkey kidney cells. Using monkey kidney cultures, Dr G. P. B. Boissard of the Virus Reference Laboratory, Colindale, isolated virus from faeces of patients E.K. taken on the sixth day of illness and from C.W. on the seventh day. These viruses were antigenically similar to virus isolated from L.R.

Table 2. Serological relationships of viruses isolated from cases of aseptic meningitis

\begin{tabular}{|c|c|c|c|}
\hline \multirow[b]{2}{*}{$\begin{array}{l}\text { Name of } \\
\text { patient }\end{array}$} & \multirow[b]{2}{*}{$\begin{array}{c}\text { Days } \\
\text { after onset }\end{array}$} & \multicolumn{2}{|c|}{$\begin{array}{l}\text { Serum titre against strain } \\
\text { of virus from each patient }\end{array}$} \\
\hline & & L.R.'s sera & $\overbrace{\text { Homologous sera }}$ \\
\hline L.R. & 3 & $\begin{array}{r}<10^{*} \\
50 \dagger\end{array}$ & $\begin{array}{r}<10^{*} \\
50 \dagger\end{array}$ \\
\hline L.M. & 2 & $\begin{array}{r}<10 \\
>100\end{array}$ & $\begin{array}{r}<10 \\
>100\end{array}$ \\
\hline E.K. & 6 & $\begin{array}{r}<10 \\
250\end{array}$ & $\begin{array}{r}50 \\
>250\end{array}$ \\
\hline C.W. & 7 & $\begin{array}{l}<10 \\
>50\end{array}$ & $\begin{array}{l}50 \\
50\end{array}$ \\
\hline B.M. & Not ill & $\begin{array}{l}<10 \\
>50\end{array}$ & $\begin{array}{r}<10 \\
>250\end{array}$ \\
\hline A.D. $\ddagger$ & 3 & $\begin{array}{l}<10 \\
>50\end{array}$ & $\begin{array}{l}250 \\
250\end{array}$ \\
\hline
\end{tabular}

Faeces were obtained from six other patients between 3 and 7 days after onset of illness. No virus was isolated when faecal extracts were inoculated into human amnion cultures (Table 3). No specimen of faeces was available from M.B., the first patient of the series.

The virus which was isolated from patient L.R. has been named 'Bourn virus strain L.R.'. For most of the tests to be described in this paper, the seed virus was tissue culture fluid either from its first passage in human amnion cultures or from its second passage in monkey kidney cultures. The isolation in monkey kidney culture was made at a time when only well-characterized viruses were being used in the laboratory and it was not due to contamination with any of these agents. The isolation in human amnion culture was made 3 months later from the same faecal extract. In human amnion cultures some cytopathogenic effect was observed 
on the third day after inoculation of faecal extract and this was complete on the fourth day. In subsequent passages, complete cytopathogenic effect was observed on the second day. The cytopathogenic effect was indistinguishable from that caused by poliomyelitis virus (Fig. 2). The titre of first and second amniotic passage virus was $10^{-6-0}$ in human amnion culture. In monkey kidney culture the cyto-

Table 3. Neutralization tests against Bourn virus

\begin{tabular}{|c|c|c|c|c|c|c|}
\hline \multicolumn{4}{|c|}{ Cases } & \multicolumn{3}{|c|}{ Contacts } \\
\hline Name & $\begin{array}{l}\text { Virus } \\
\text { isolation } \\
\text { in faeces } \\
\text { (strain) }\end{array}$ & $\begin{array}{l}\text { Days } \\
\text { after } \\
\text { onset }\end{array}$ & $\begin{array}{l}\text { Antibody } \\
\text { titre against } \\
\text { Bourn virus }\end{array}$ & Name & $\begin{array}{l}\text { Days } \\
\text { after } \\
\text { first } \\
\text { case }\end{array}$ & $\begin{array}{l}\text { Antibody } \\
\text { titre against } \\
\text { Bourn virus }\end{array}$ \\
\hline M.B. & $\begin{array}{c}\text { Not } \\
\text { tested }\end{array}$ & $\begin{array}{r}7 \\
20\end{array}$ & $\begin{array}{l}>250 \\
>250\end{array}$ & B.M. & $\begin{array}{l}23 \dagger \\
43\end{array}$ & $\begin{array}{l}<10 \\
>50\end{array}$ \\
\hline R.C. & 0 & $\begin{array}{r}4 \\
16\end{array}$ & $\begin{array}{r}50 \\
>250\end{array}$ & H.Z.B. & $\begin{array}{l}24 \\
49\end{array}$ & $\begin{array}{l}<10 \\
<10\end{array}$ \\
\hline M.M. & 0 & $\begin{array}{r}5 \\
20\end{array}$ & $\begin{array}{l}>250 \\
>250\end{array}$ & Ro.C. & $\begin{array}{l}23 \\
43\end{array}$ & $\begin{array}{l}>100 \\
>100\end{array}$ \\
\hline I.M. & 0 & $\begin{array}{r}3 \\
16\end{array}$ & $\begin{array}{r}50 \\
250\end{array}$ & E.A.C. & $\begin{array}{l}23 \\
43\end{array}$ & $\begin{array}{l}10 \\
10\end{array}$ \\
\hline C.W. & $+^{*}$ & $\begin{array}{r}6 \\
18\end{array}$ & $\begin{array}{l}250 \\
250\end{array}$ & P.L. & $\begin{array}{l}23 \\
43\end{array}$ & $\begin{array}{l}>100 \\
>100\end{array}$ \\
\hline E.K. & $+^{*}$ & $\begin{array}{r}5 \\
17\end{array}$ & $\begin{array}{r}<10 \\
50\end{array}$ & D.L. & $\begin{array}{l}23 \\
43\end{array}$ & $\begin{array}{l}>100 \\
>100\end{array}$ \\
\hline G.R. & 0 & $\begin{array}{r}5 \\
18\end{array}$ & $\begin{array}{r}<10 \\
>250\end{array}$ & E.R.R. & $\begin{array}{l}23 \\
43\end{array}$ & $\begin{array}{l}>100 \\
>100\end{array}$ \\
\hline L.R. & + & $\begin{array}{r}3 \\
16\end{array}$ & $\begin{array}{r}<10 \\
50\end{array}$ & J.R. & $\begin{array}{l}23 \\
43\end{array}$ & $\begin{array}{l}>100 \\
>100\end{array}$ \\
\hline L.M. & + & $\begin{array}{r}2 \\
13\end{array}$ & $\begin{array}{r}<10 \\
250\end{array}$ & P.R. & $\begin{array}{l}23 \\
49\end{array}$ & $\begin{array}{l}<10 \\
>50\end{array}$ \\
\hline H.D.M. & 0 & $\begin{array}{r}3 \\
13\end{array}$ & $\begin{array}{r}<10 \\
>250\end{array}$ & B.R. & 21 & $<10$ \\
\hline R.K. & 0 & $\begin{array}{r}5 \\
14\end{array}$ & $\begin{array}{l}>250 \\
>250\end{array}$ & A.R. & 21 & 10 \\
\hline & & & & A.C. & 27 & $>\mathbf{5 0}$ \\
\hline & & & & L.C.M. & 23 & $<10$ \\
\hline & & & & B.B. & 24 & 50 \\
\hline
\end{tabular}

* Isolated in monkey kidney culture by Dr G. P. B. Boissard.

$\dagger$ Bourn virus isolated from a rectal swab collected on this date.

pathogenic effect was complete on the second day in the case of primary isolation, second passage and third passage. The titre of second passage virus was $10^{-60}$ in both monkey kidney and human amnion cultures.

Bourn virus in second amniotic passage passed through a Seitz EK filter without loss of titre. Virus in first amniotic passage and second monkey kidney passage has been stored at $-20^{\circ} \mathrm{C}$. without loss of titre for over 3 months despite repeated freezing and thawing. Some infectivity was preserved by lyophilization in a centrifugal freeze drier, but the titre was reduced about $10^{4}$ times. 
Strains of Bourn virus which were isolated from L.R. and L.M. were not neutralized by antiserum prepared against poliomyelitis Types 1, 2 and 3. Strain L.R. was not neutralized by antisera to Types $A_{2}, A_{3}, A_{4}, A_{5}, A_{6}, A_{9}, B_{1}, B_{3}, B_{4}$ and $B_{5}$ Coxsackie viruses. These Coxsackie antisera were kindly supplied by Dr D. A. J. Tyrrell. The strains of virus which were isolated from patients E.K. and C.W. were not neutralized by poliomyelitis antisera Types 1, 2, 3 (Boissard, personal communication).

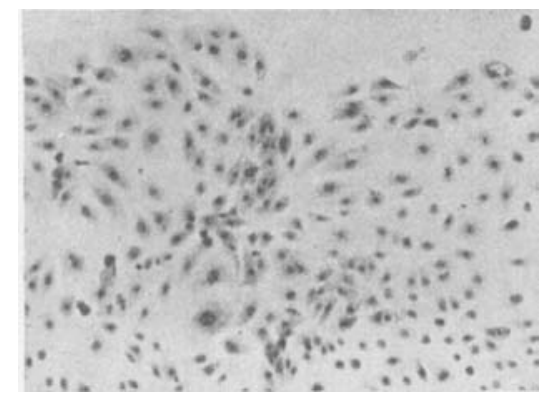

Uninoculated culture, 11 days growth $(\times 120)$

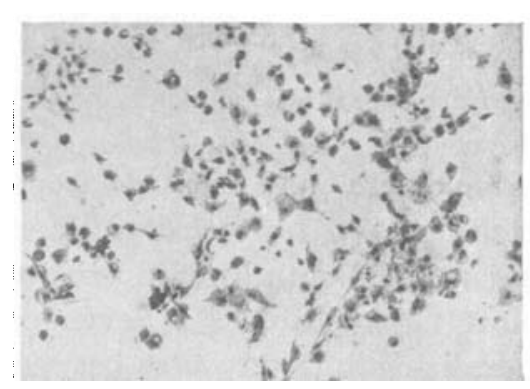

Culture infected 2 days previously with Bourn virus $(\times 120)$

Fig. 2. Cultures of human amnion cells.

Lyophilized Bourn virus was sent to Dr J. L. Melnick of Yale University, Section of Preventive Medicine. He has reported that 'Bourn' virus belongs to the ECHO group of viruses, Type 9 (McLean \& Melnick, 1957).

Inoculation of $10^{5}$ infective doses of human amniotic and monkey kidney passage virus failed consistently to cause any cytopathogenic effect in cultures of human epithelial cells strain HeLa.

A total of eleven litters of newborn mice were injected intracerebrally with Bourn virus strain L.R. Each mouse received $10^{4}$ TCD of virus suspension in maintenance medium. Deaths which occurred before the fourth day after inoculation were not considered due to virus. One or more mice in each of five litters remained normal for at least 11 days after injection. In each of six litters some mice were found dead between 5 and 11 days after injection, but these mice were not sick on the previous day. Eight mice which came from six litters showed generalized wasting and weakness in one or more limbs 1 day before death. Virus concentration was high in the torsos of sick mice but low in the brains. Passage of torso suspension intracerebrally to other newborn mice at $10^{-1}$ dilution caused wasting and limb paralysis in four mice out of six belonging to one litter 9-10 days after injection. Virus was present in high titre in the torsos of these mice.

A total of ten litters of newborn mice were injected intracerebrally with maintenance medium only. All mice in five litters died between 2 and 7 days after inoculation, but some mice in the remaining five litters survived at least 11 days.

Histological sections were prepared from brain and anterior abdominal wall of mice 5-10 days after inoculation of Bourn virus. Changes suggestive of infection with Coxsackie A virus were detected. 
No illness was produced following inoculation of Bourn virus into weaned mice 3-4 weeks old either by the intracerebral or the intraperitoneal route. No lesions were detected following inoculation of Bourn virus into the yolk sac or on the chorio-allantois of fertile hen eggs.

Thus Bourn virus belongs to the ECHO group but it also resembles Coxsackie A virus because it may produce weakness and paralysis in a few newborn mice after injection of large amounts of virus, though this ability to cause illness in mice did not increase after two mouse passages.

\section{Neutralization tests}

Paired sera were obtained from all eleven clinical cases. Early sera were collected between 2 and 7 days after onset and late sera were obtained 13-20 days after onset. Neutralization tests were performed on these sera, using 1000 TCD of Bourn virus (Table 3). Seven cases showed a fivefold or greater increase in neutralizing antibody titre between the first and second serum samples. Five of these seven cases had no antibody in the first serum, but two had titres of 50 on the third and fourth days of illness. The remaining four cases whose sera showed no rising titre all had a titre of 250 or greater when they were bled initially on the fifth, sixth or seventh day of illness.

Sera were obtained from fourteen family contacts of the Bourn cases 23 days after the first case occurred. Of these, eight had a neutralizing antibody titre of 50 or greater, in two the titre was 10 , and four sera had no antibody (Table 3). Further serum samples were obtained from nine of these subjects 43 days after the first case occurred. None of these subjects had been ill meanwhile. In seven subjects the antibody titre was unchanged. Two subjects B.M. and P.R. had no antibody in the first serum sample but antibody was detected in the second sample. Bourn virus was isolated from a rectal swab which was taken from B.M. at the time the first serum sample was collected, but no virus was detected in a rectal swab taken from P.R.

Attempts were made to isolate virus from faeces of four other patients who were admitted to hospital at the same time as the Bourn cases. Two of these were diagnosed clinically as suffering from non-paralytic poliomyelitis. Type 1 poliomyelitis virus was isolated from both cases. No antibody to the Bourn virus was detected in acute or convalescent sera taken from either patient. The other two cases were diagnosed as suffering from aseptic meningitis, but neither had contact with the Bourn cases. No virus was isolated from the faeces of either case, but one patient had a rising titre of antibody to Bourn virus and the other patient had antibody in both the acute and convalescent sera.

Virus isolations were attempted from faeces of sixteen patients who were admitted to Brookfields Hospital between 1 January and 31 July 1956. Human amnion cultures were always used. Amongst the six patients who suffered from aseptic meningitis, virus was isolated from one case, A.D. This virus was not poliomyelitis but serologically it was related to Bourn virus (Table 2). Of the four patients who were admitted with non-paralytic poliomyelitis, all were excreting 
Type 3 poliomyelitis virus in the stools. In the group of six patients with paralytic poliomyelitis, Type 3 poliomyelitis virus was isolated from three patients and Type 1 poliomyelitis virus was isolated from another two patients.

\section{DISCUSSION}

These cases of aseptic meningitis differed from pyogenic meningitis mainly by the lesser degree of neck stiffness and the predominantly lymphocytic or mixed lymphocytic and granulocytic response in the CSF which was associated with a normal or low leucocyte count in the peripheral blood.

These cases may be distinguished readily from cases of benign myalgic encephalomyelitis (Lancet, 1956). In the present cases of aseptic meningitis the onset was sudden, there were no objective sensory or motor disturbances, there was a pleocytosis in the CSF and complete recovery occurred in less than 3 weeks. In cases of benign myalgic encephalomyelitis the onset was insidious, some changes in sensation were observed and transient muscular paresis occurred, the CSF was normal and the course of illness was protracted (Ramsay \& O'Sullivan, 1956).

The diagnosis of aseptic meningitis was made in these patients because they had no known contact with recent cases of poliomyelitis. The diagnosis of 'nonparalytic poliomyelitis' is usually made if the patient exhibits the above syndrome together with a history of recent contact with cases of paralytic poliomyelitis. Our experience in Cambridge has shown that poliomyelitis virus may frequently be isolated from cases of non-paralytic poliomyelitis and this is in accord with results elsewhere (Melnick, 1954).

The high degree of infectiousness of cases in the Bourn epidemic of aseptic meningitis is in sharp contrast to the apparently low degree of infectiousness of sporadic cases of aseptic meningitis which have occurred in Cambridgeshire at the rate of approximately six per year during the past 5 years. In the case of the Bourn epidemic, symptomatic infection was transmitted to two nurses who cared for the first two patients as well as to other family contacts. Of seventeen members of four Bourn families whose final serum sample neutralized Bourn virus at titre $>10$, eight were infected at a clinical level and nine received subclinical infections. Recovery of Bourn virus from the rectal swab taken from one asymptomatic contact, followed by the production of neutralizing antibody against this virus, showed that subclinical infections could occur with this virus.

\section{SUMMARY}

Eleven cases of aseptic meningitis occurred in a Cambridgeshire village between 17 October and 11 November 1955. The syndrome consisted of severe headache, backache, vomiting, fever and neck stiffness together with lymphocytes and frequently some granulocytes in the cerebrospinal fluid. Principally, it affected persons aged between 10 and 30 years. Out of a total population twenty-three at risk, seventeen were infected and eight became ill. A further three contacts who were living in Cambridge became ill.

Identical strains of virus were isolated from the faeces of two patients by inocula- 
tion of trypsin-dispersed human amnion cells and from the faeces of another two patients by inoculation of monkey kidney cultures. Bourn virus, which belonged to the ECHO group, Type 9, multiplied readily and produced cytopathogenic effects in human amnion and monkey kidney cultures, but it was not cytopathogenic in HeLa cell cultures. These investigations strongly suggest that Bourn virus caused the epidemic.

We wish to thank Dr M. G. P. Stoker for his advice and criticism and Mrs B. M. Cook for technical assistance.

We are indebted to Dr J. O’H. Tobin and Dr F. K. Sanders for advice on certain technical procedures.

It is a pleasure to acknowledge the assistance given by many colleagues and friends, including Dr D. I. Annear, Miss D. K. Bell, Mrs D. Ditchburn, Dr R. M. Fry, Dr D. Gairdner, Dr J. E. Power, Dr D. Simpson, Dr P. Tyzer and Dr P. J. Wormald.

\section{REFERENCES}

BarretT, A. M., Gairdner, D. \& McFarlan, A. M. (1952). Brit. med. J. i, 1317.

COMMITTEE ON THE ECHO viRUSES (1955). Science, 122, 1187.

Curnen, E. C., Shaw, E. W. \& Melnick, J. L. (1949). J. Amer. med. Ass. $141,894$.

Dulbecco, R. \& Vogt, M. (1954). J. exp. Med. 99, 167.

Enders, J. F., Beli, J. A., Dingle, J. H., Francis, T. Jr., Hilreman, M. R., Huebner, R. J. \& PAYNE, A. M-M. (1956). Science, 124, 119.

GEY, G. O. (1949). Bulletin of the Tissue Culture Commission, March 16, 1949.

Honta, E. I., Melnick, J. L., Isacson, P., Parr, R., Myers, I. L. \& Watton, M. (1956). J. exp. Med. 103, 247.

Huston, A. F., Morwood, J. B., Christofinis, G. J. \& Wood, W. (1956). Brit. med. J. ii, 629.

KmBRICK, S., Enders, J. F. \& RobBins, F. C. (1955). J. Immunol. 75, 391.

Lancet (1956). Annotation 'Benign Myalgic Encephalomyelitis', i, 789.

Mclean, D. M. \& Melnick, J. L. (1957). Proc. Soc. exp. Biol., N.Y., 94, 656.

Melnick, J. L. (1954). Amer. J. publ. Hlth, 44, 571.

Morgan, J. F., Morton, H. J. \& Parker, R. C. (1950). Proc. Soc. exp. Biol., N.Y., 73, 1. Ramsay, A. M. \& O'Sullivan, E. (1956). Lancet, i, 761.

Svedmye, A., Melen, B. \& KJellen, L. (1956). Acta med. scand. 154, Suppl. 316, p. 20.

Syverton, J. T. (1956). Amer. J. trop. Med. Hyg. 5, 430.

Zitcer, E. M., Fogh, J. \& Dunnebacke, T. H. (1955). Science, 122, 30.

(MS. received for publication 26. x. 56) 